\title{
Pengaruh Pembelajaran Menggunakan Strategi Konflik Kognitif terhadap Perubahan Konsep tentang Gerak pada Siswa Kelas X MAN 2 Model Palu
}

\author{
Filda Ambo Tayeb, Muslimin dan Jusman Mansyur \\ e-mail: Fildaambotayeb@yahoo.com \\ Program Studi Pendidikan Fisika FKIP Universitas Tadulako \\ Jl. Soekarno Hatta Km. 9 Kampus Bumi Tadulako Tondo Palu - Sulawesi Tengah
}

\begin{abstract}
Abstrak - Penelitian ini bertujuan untuk mengetahui pengaruh pembelajaran menggunakan strategi konflik kognitif terhadap perubahan konsep tentang gerak pada siswa Kelas X MAN 2 Model Palu. Penelitian ini menggunakan pre-experimental dengan desain one group pretest-postest design. Subjek penelitian terdiri dari 16 siswa dari Kelas X MIA 4 yang terdaftar pada Tahun Ajaran 2014/2015. Pengambilan data dilakukan dengan menggunakan tes pemahaman konsep dan wawancara. Wawancara dilakukan untuk menganalisis perubahan konsep. Data penelitian dianalisis menggunakan pendekatan kuantitatif dan deskriptif-kualitatif. Pengujian hipotesis menggunakan statistik non-parametrik dengan uji Wilcoxon pada taraf signifikansi 0,05. Hasil penelitian menunjukkan bahwa terdapat pengaruh strategi konflik kognitif terhadap perubahan konsep tentang gerak.
\end{abstract}

Kata Kunci: startegi, konflik kognitif, dan perubahan konsep

\section{PENDAHULUAN}

Teori kontruktivisme menyatakan bahwa pengetahuan dibentuk (dikonstruksi) oleh siswa sendiri dengan lingkungan, tantangan dan bahan yang dipelajari ${ }^{[1]}$. Siswa merekonstruksi pengetahuan mereka berdasarkan pengalaman. Melalui pengalaman memungkinkan siswa menciptakan skema di benaknya. Skemaskema ini dapat dapat berubah, diperluas melalui proses asimilasi dan akomodasi [2].

Perubahan konsep asimilasi dan akomodasi inilah yang dimaksud peneliti sebagai pembenahan. Pembenahan dapat diartikan sebagai mengubah dari konsep yang salah menuju konsep yang benar.

Penelitian Meidahrianti dkk. menyimpulkan bahwa pembelajaran dengan menggunakan strategi konflik kognitif [3] dapat menimbulkan perubahan konsep pada siswa dan $\mathrm{N}$-gain dalam kategori tinggi. Hal ini menunjukkan bahwa peningkatan pemahaman konsep siswa sangat baik.

Penelitian berkaitan tentang miskonsepsi fisika sudah cukup banyak dilakukan di Indonesia, namun belum bisa mengatasi miskonsepsi siswa [4]. Penanganan miskonsepsi selalu berkaitan dengan perubahan konsep.

Banyak penelitian telah dilakukan untuk mengungkap pemahaman siswa tentang konsep-konsep gerak. Beberapa penelitian menunjukkan banyak siswa dan mahasiswa yang mempunyai konsepsi salah terkait dengan materi gerak [4]. Penelitian yang dilakukan oleh Pujianto dkk. [5] menemukan bahwa pada kinematika gerak lurus sebesar 50,00\% siswa mengalami miskonsepsi dan siswa dengan pemahaman konsep kinematika gerak lurus yang baik hanya sebesar $21,67 \%$. Namun, sejauh ini di Indonesia masih sedikit penelitian yang mengungkap konsepsi dan perubahan konsep siswa terkait dengan pengalaman belajar siswa di kelas.

Berdasarkan permasalahan di atas, maka penulis melakukan penelitian dengan tujuan untuk mengetahui pengaruh pembelajaran menggunakan strategi konflik kognitif terhadap perubahan konsep tentang gerak. Fokus penelitian kali ini yaitu pada materi gerak lurus beraturan (GLB) dan gerak lurus berubah beraturan (GLBB) dimana konsep yang akan digali yaitu tentang konsep gerak.

\section{METODE PENELITIAN}

Jenis penelitian ini yaitu penelitian yang bersifat kuantitatif dengan rancangan pre-experimental dengan menggunakan satu kelas eksperimen. Namun, aspek-aspek yang berkaitan dengan perubahan konsep dianalisis menggunakan pendekatan kualitatif.

Desain penelitian yang digunakan adalah "one group pretest-postest design" yaitu desain penelitian yang digunakan dengan cara memberikan pretest dan posttest dengan hanya menggunakan satu kelas saja yang dijadikan sebagai kelas eksperimen. Menurut Arikunto [6] desain ini dapat dilihat pada Tabel 1. 
TABEL 1. Desain Satu Kelompok Pretest-Posttest (One group pretest-posttest design)

\begin{tabular}{cccc} 
Kelompok & Pretest & Perlakuan & Posttest \\
E & $\mathrm{O}$ & $\mathrm{X}$ & $\mathrm{O}$ \\
\hline
\end{tabular}

Keterangan:

E : Kelas eksperimen

$X$ : Perlakuan dengan strategi kognitif

O : Pretest atau posttest

Penelitian ini dilakukan di MAN 2 Model Palu. Populasi penelitian ini adalah seluruh siswa Kelas X MAN 2 Model Palu pada Semester Ganjil Tahun Ajaran 2014/2015 yang berjumlah 135 orang. Cara penarikan sampel dalam penelitian ini yaitu menggunakan teknik cluster random sampling yaitu pengambilan sampel secara acak [7]. Dari sejumlah kelas yang ada kemudian dipilih secara acak satu kelas yang dijadikan sampel. Sampel yang digunakan dalam penelitian ini berjumlah 16 orang.

Penelitian ini menggunakan instrumen berupa tes pemahaman konsep berbentuk essay yang terdiri dari 5 soal. Setiap item soal telah divalidasi oleh validator ahli.

Data yang dikumpulkan berupa hasil tes awal (pretest), tes akhir (posttest), dan wawancara. Tes yang digunakan pada tes awal sama dengan tes akhir.

Berdasarkan deskripsi pada saat pretest dan posttest yang dijadikan responden serta hasil wawancara maka dapat dianalisis bagaimana perubahan konsep yang terjadi.

\section{HASIL DAN PEMBAHASAN}

Hasil Tes Perubahan Konsep tentang Gerak

Setelah dilakukan perhitungan, perubahan konsep tentang gerak diperoleh data hasil penelitian. Berdasarkan Tabel 2 dapat diketahui skor pretest, posttest dan $\mathrm{N}$ gain.

TABEL 2 Perolehan skor pretest, posttest dan N gain

\begin{tabular}{cccccc} 
No & $\begin{array}{c}\text { Kode } \\
\text { Siswa }\end{array}$ & $\begin{array}{c}\text { Skor } \\
\text { Pretest } \\
(\%)\end{array}$ & $\begin{array}{c}\text { Skor } \\
\text { Posttest } \\
(\%)\end{array}$ & $\begin{array}{c}\text { N-gain } \\
\mathbf{( \% )}\end{array}$ & Kategori \\
\hline 1 & K-01 & 5,60 & 67,60 & 65,68 & Sedang \\
2 & K-02 & 5,60 & 69,60 & 67,80 & Sedang \\
3 & K-03 & 6,40 & 52,80 & 49,57 & Sedang \\
4 & K-04 & 5,60 & 48,40 & 45,34 & Sedang \\
5 & K-06 & 5,60 & 59,20 & 56,78 & Sedang \\
6 & K-11 & 0,80 & 70,00 & 69,76 & Sedang \\
7 & K-12 & 13,52 & 85,60 & 83,35 & Tinggi \\
8 & K-13 & 4,00 & 43,20 & 40,83 & Sedang \\
9 & K-14 & 5,60 & 76,80 & 75,42 & Tinggi \\
10 & K-15 & 25,60 & 53,60 & 37,63 & Sedang
\end{tabular}

ISSN 23383240

\begin{tabular}{|c|c|c|c|c|c|}
\hline No & $\begin{array}{l}\text { Kode } \\
\text { Siswa }\end{array}$ & $\begin{array}{c}\text { Skor } \\
\text { Pretest } \\
(\%)\end{array}$ & $\begin{array}{c}\text { Skor } \\
\text { Posttest } \\
(\%)\end{array}$ & $\begin{array}{c}\text { N-gain } \\
(\%)\end{array}$ & Kategori \\
\hline 12 & $\mathrm{~K}-17$ & 25,60 & 61,60 & 48,39 & Sedang \\
\hline 13 & $\mathrm{~K}-18$ & 25,60 & 54,40 & 38,71 & Sedang \\
\hline 14 & $\mathrm{~K}-20$ & 5,60 & 24,00 & 19,49 & Rendah \\
\hline 15 & $\mathrm{~K}-21$ & 25,60 & 68,40 & 57,53 & Sedang \\
\hline 16 & $\mathrm{~K}-23$ & 5,60 & 70,40 & 68,64 & Sedang \\
\hline \multicolumn{2}{|c|}{ Jumlah } & 171,92 & 953,60 & 869,84 & \\
\hline \multicolumn{2}{|c|}{ Rerata } & 10,74 & 59,60 & 54,36 & Sedang \\
\hline
\end{tabular}

Rerata $\mathrm{N}$-gain untuk setiap soal yang digunakan dalam penelitian ini dapat dilihat pada Tabel 3.

TABEL 3 Tingkat Ketercapaian N-gain Tiap Soal

\begin{tabular}{|c|c|c|c|c|c|}
\hline \multirow{2}{*}{$\begin{array}{l}\text { No } \\
\text { soal }\end{array}$} & \multirow{2}{*}{ Konsep } & \multicolumn{2}{|c|}{ Skor } & \multirow{2}{*}{$\begin{array}{l}\text { Gain } \\
(\%)\end{array}$} & \multirow{2}{*}{ Kategori } \\
\hline & & Pretest & Posttest & & \\
\hline 1 & Gerak relatif & 6,66 & 48,66 & 44,99 & Sedang \\
\hline 2 & $\begin{array}{l}\text { Jarak dan } \\
\text { perpindahan }\end{array}$ & 15,50 & 43,00 & 32,54 & Sedang \\
\hline 3 & Kelajuan & 0,00 & 81,25 & 81,25 & Tinggi \\
\hline 4 & GLB & 25,00 & 57,60 & 43,47 & Sedang \\
\hline 5 & $\begin{array}{l}\text { Gerak jatuh } \\
\text { bebas }\end{array}$ & 0,00 & 77,60 & 77,60 & Tinggi \\
\hline
\end{tabular}

\section{Uji Hipotesis}

pengujian hipotesis menggunakan statistik non parametrik Pengujian hipotesis menggunakan uji Wilcoxon (uji satu pihak) ${ }^{[8]}$. Uji Wilcoxon digunakan untuk membandingkan dua variabel pada sampel yang sama.

Kriteria $\mathrm{H}_{0}$ diterima jika $\mathrm{W}_{\text {hitung }}>\mathrm{W}_{\text {Tabel }}$ dan taraf nyata $\alpha=0,05$, untuk harga W lainnya $\mathrm{H}_{0}$ ditolak. Berdasarkan daftar distribusi diperoleh $\mathrm{W}_{\text {Tabel }}=35$ sedangkan dari hasil perhitungan uji Wilcoxon diperoleh nilai $\mathrm{W}_{\text {hitung }}=0$ yang berada di luar penerimaan $\mathrm{H}_{0}$, hal ini berarti $\mathrm{W}_{\text {Tabel }}>\mathrm{W}_{\text {hitung, }}$ dengan demikian $\mathrm{H}_{0}$ ditolak pada taraf nyata $\alpha=0,05$.

\section{Hasil Wawancara}

Berikut ditampilkan deskripsi jawaban pretest, posttest dan kutipan jawaban peneliti dengan responden.

\section{a) Soal No. 1}

Soal No. 1 tentang konsep gerak relatif. Soal ini menanyakan apakah seorang teman yang sedang berdiri dipinggir jalan, dapat dikatakan bergerak atau tidak. Untuk lebih jelasnya, perubahan konsep Responen K-02 mengenai konsep gerak relatif dapat dilihat pada Tabel 4 .

Berdasarkan Tabel 4, dapat dilihat bahwa pemahaman responden terkait soal No. 1 memberikan gambaran bahwa Responden K-02 mula-mula belum memahami tentang konsep 
gerak relatif. Menurut Responden K-02 teman yang sedang berdiri di pinggir jalan itu diam atau tidak bergerak, yang bergerak adalah mobil. Setelah dilakukan proses belajar mengajar srategi konflik kognitif Responden K02 sudah mulai memahami tentang konsep gerak relatif. Menurut Responden K-02, untuk menentukan suatu benda dikatakan bergerak harus ditentukan dulu titik acuannya dimana. Teman yang berdiri dipinggir jalan dapat dikatakan bergerak jika titik acuannya adalah mobil dan teman bisa dikatakan tidak bergerak jika titik acuan ada pada dirinya sendiri.

TABEL 4 Perbandingan jawaban pretest dan posttest Responden K-02

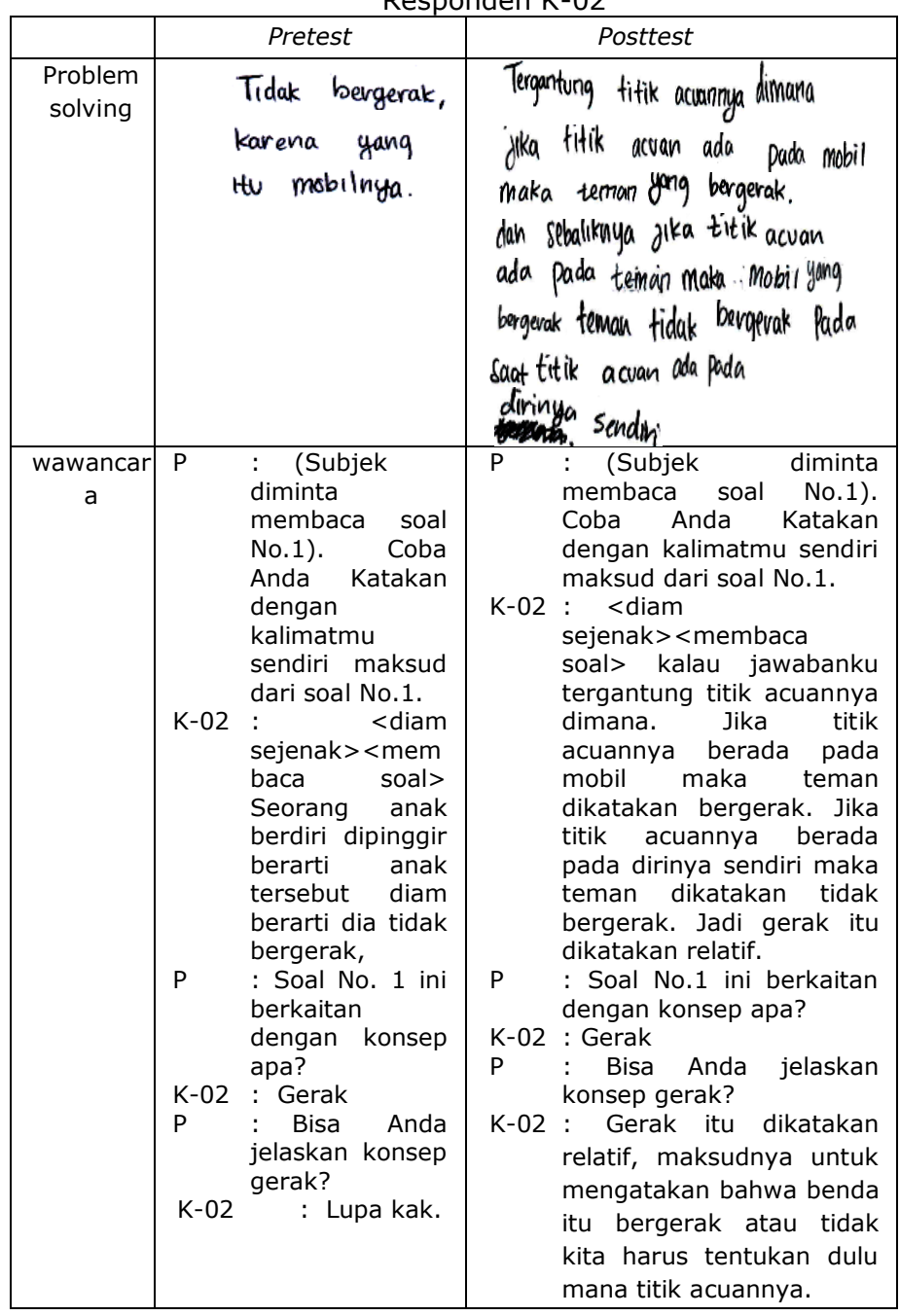

b) Soal No. 2

Soal No. 2 tentang konsep jarak dan perpindahan. Disajikan suatu gambar lintasan yang ditempuh tiga rombongan gerak jalan dari kantor gubernur sebagai posisi awal ke lapangan Vatulemo sebagai tujuan akhir dengan rute yang berbeda. Soal ini menanyakan tentang bagaimana jarak dan besar perpindahan yang ditempuh oleh ke tiga rombongan. untuk lebih jelasnya, perubahan konsep Responen K-12 mengenai konsep jarak dan perpindahan dapat dilihat pada Tabel 5.

Berdasarkan Tabel 5, dapat dilihat bahwa pemahaman responden terkait soal No. 2 memberikan gambaran bahwa bahwa Responden K-04 mula-mula belum memahami tentang konsep jarak dan perpindahan. Setelah dilakukan proses belajar mengajar dengan menggunakan strategi konflik kognitif Responden K-04 sudah mulai memahami perbedaan antara konsep jarak dan perpindahan. Menurut Responden K-04 jarak dari kantor ke lapangan adalah panjang seluruh lintasan yang dilalui oleh ketiga rombongan. Jarak antara tiga rombongan masing-masing berbeda. Perpindahan merupakan perubahan posisi suatu benda yang bergantung pada posisi awal dan posisi akhir. Tidak peduli bentuk lintasannya seperti apa sehinggga besar perpindahan dari ketiga rombongan adalah sama. Responden K-04 mulai memahami bahwa jarak akan selalu sama dengan besar perpindahannya jika lintasan yang ditempuh oleh suatu benda berupa garis lurus.

TABEL 5 Perbandingan jawaban pretest dan posttest

\begin{tabular}{|c|c|c|}
\hline & Pretest & Posttest \\
\hline $\begin{array}{l}\text { Problem } \\
\text { Solving }\end{array}$ & 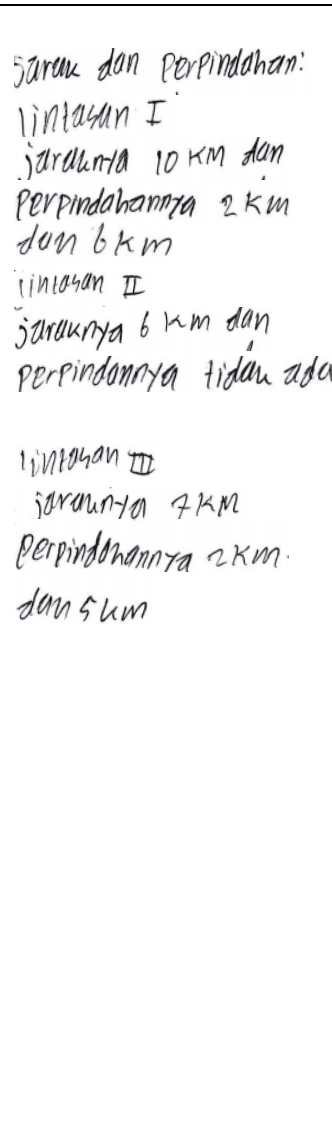 & 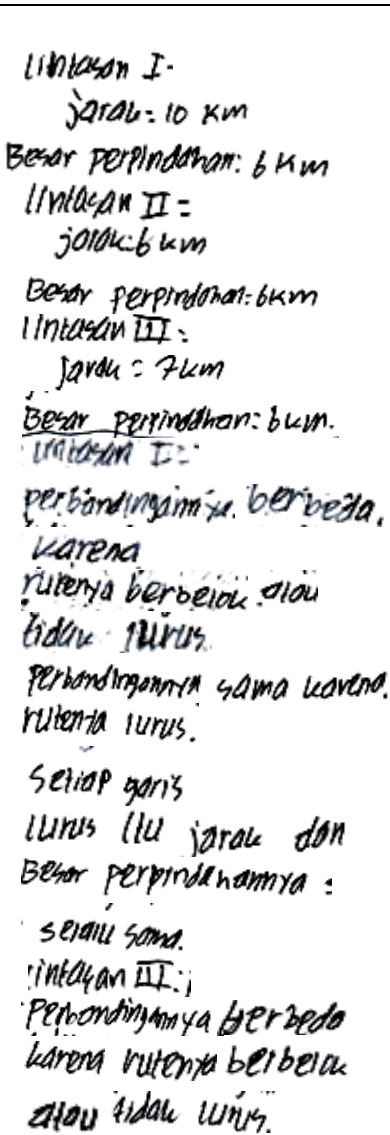 \\
\hline
\end{tabular}




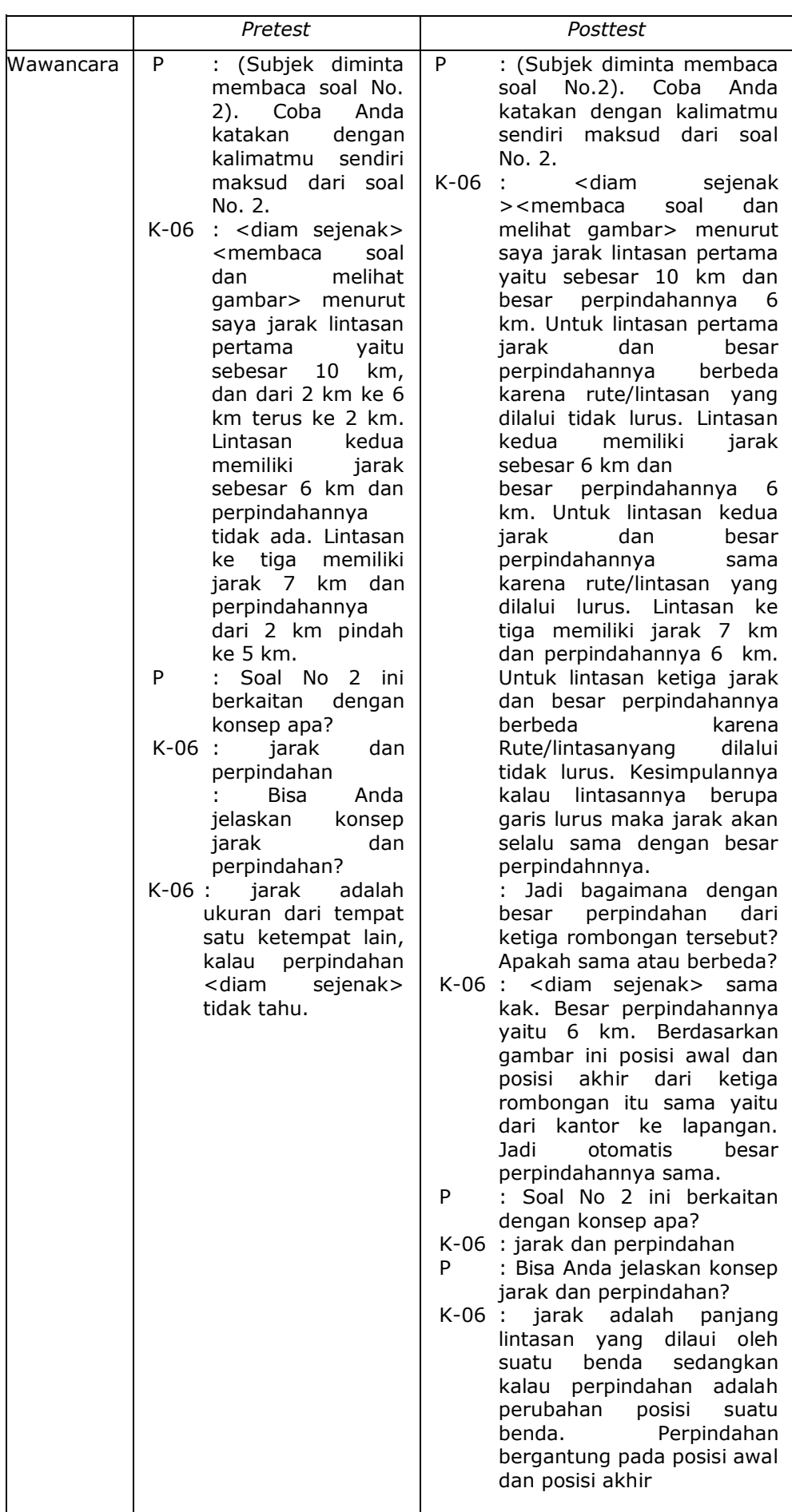

\section{c) Soal No. 3}

Soal No. 3 tentang konsep kelajuan. Soal ini menanyakan besaran apa yang ditunjukkan pada jarum speedometer kendaraan bermotor. Untuk lebih jelasnya, perubahan konsep Responen K-02 mengenai konsep kelajuan dapat dilihat pada Tabel 6 .

Berdasarkan Tabel 6, dapat dilihat bahwa pemahaman responden terkait soal No. 3 memberikan gambaran bahwa Responden K-01 mula-mula belum memahami tentang konsep kelajuan. Menurut Responden K-01, pada speedometer kendaraan bermotor menunjukan besaran kecepatan. Soal No. 3, kebanyakan responden menjawab pada speedometer kendaraan bermotor menunjukkan besaran kecepatan, sebab menurut resonden speedometer itu mengukur kecepatan yang ditempuh oleh pengendara motor. Responden belum bisa membedakan antara konsep kelajuan dan kecepatan. Kelajuan merupakan besaran skalar yang bergantung pada nilai, sedangkan kecepatan merupakan besaran vektor yang bergantung pada nilai dan arah. Setelah dilakukan proses belajar mengajar dengan menggunakan strategi konflik kognitif Responden K-01 sudah mulai memahami perbedaan antara konsep kelajuan dan kecepatan. Menurut Responden K-01 Penunjukan jarum yang terbaca pada speedometer kendaraan bermotor menunjukkan besaran kelajuan sebab speedometer tidak bergantung pada arah gerak.

TABEL 6 Perbandingan jawaban pretest dan posttest

\begin{tabular}{|c|c|c|}
\hline & Pretest & Posttest \\
\hline $\begin{array}{l}\text { Problem } \\
\text { Solving }\end{array}$ & $\begin{array}{l}\text { Besaran Turunan karna } \\
\text { speedmeter motor } \\
\text { mengukur kecepatan }\end{array}$ & $\begin{array}{l}\text { Besaran skalar kelajuan } \\
\text { karena spidometernya } \\
\text { tidak menentukan } \\
\text { arah. }\end{array}$ \\
\hline Wawancara & 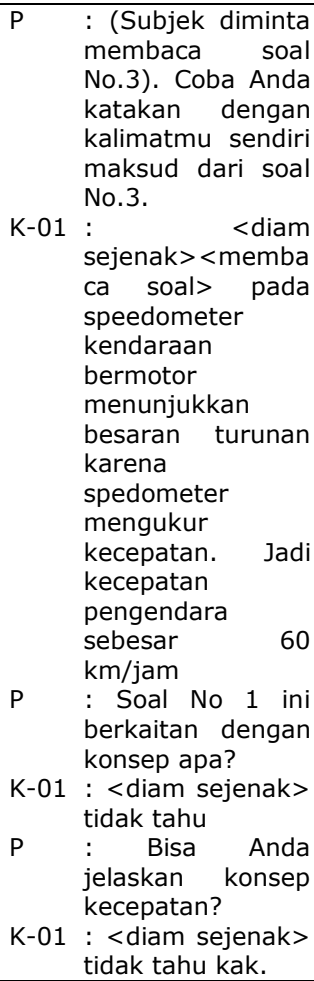 & 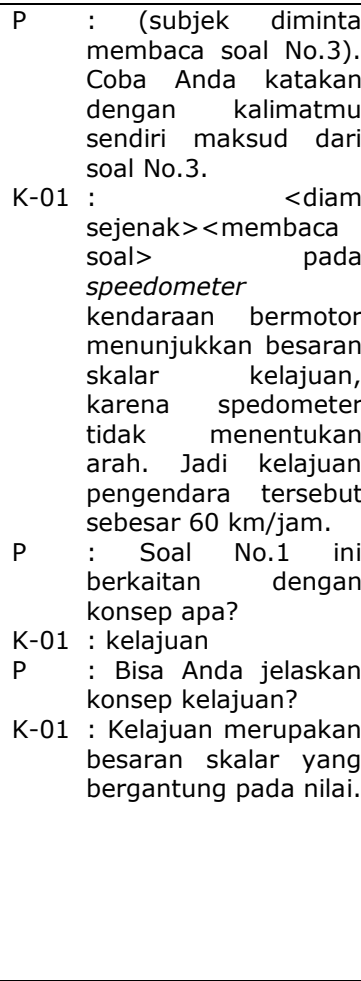 \\
\hline
\end{tabular}




\section{d) Soal No 4}

Soal No. 4 tentang konsep gerak lurus beraturan (GLB). Soal ini menanyakan tentang tanggapan siswa apakah sepakat dengan pendapat yang mengatakan selama 10 menit bus tidak mengalami percepatan atau selama 10 menit bus mengalami percepatan tetapi percepatannya tetap. Untuk lebih jelasnya, perubahan konsep Responen K-23 mengenai konsep gerak lurus beraturan dapat dilihat pada Tabel 7.

TABEL 7 Perbandingan jawaban pretest dan posttest Responden $\mathrm{K}-23$

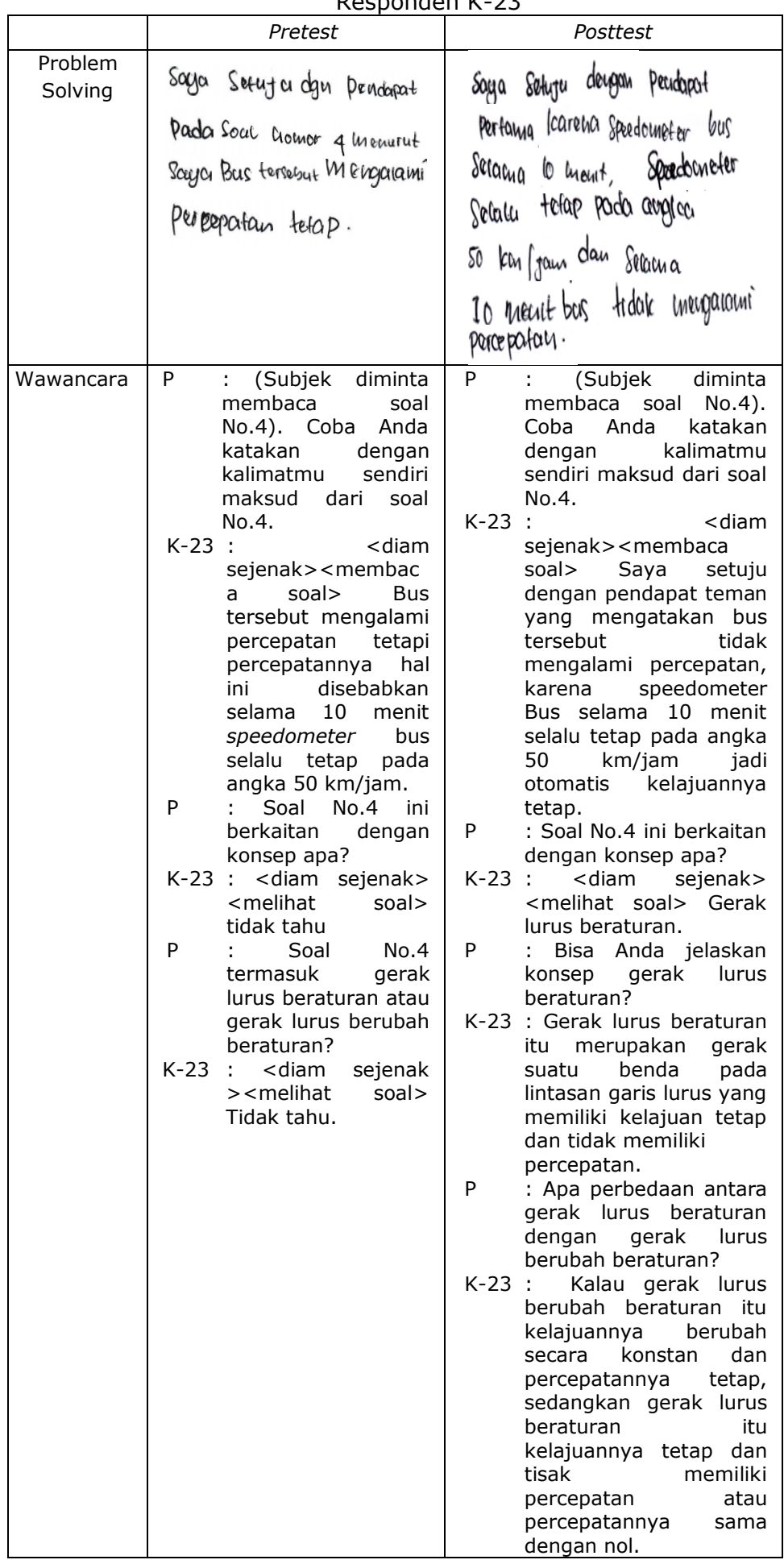

Berdasarkan Tabel 7, dapat dilihat bahwa pemahaman responden terkait soal No. 4 memberikan gambaran bahwa Responden K-23 mula-mula belum memahami tentang konsep gerak lurus beraturan. Responden K-23 sepakat bahwa selama 10 menit bus mengalami percepatan tetapi percepatannya tetap hal ini disebabkan selama 10 menit speedometer bus selalu tetap pada angka $50 \mathrm{~km} / \mathrm{jam}$. Setelah dilakukan proses belajar mengajar dengan menggunakan strategi konflik kognitif Responden K-23 sudah mulai memahami tentang konsep gerak lurus beraturan. Responden K-23 yakin bahwa bus tidak mengalami percepatan karena selama 10 menit speedometer bus selalu tetap pada angka 50 $\mathrm{km} / \mathrm{jam}$ berarti kelajuannya tetap.

\section{e) Soal No. 5}

Soal No. 5 tentang konsep gerak jatuh bebas. Soal ini menanyakan dua buah bola terbuat dari besi dan aluminium (massa besi lebih dua kali massa aluminium) dilepaskan pada saat yang sama dan dari ketinggian yang sama. Apabila dilakukan dari atas rumah lantai dua, bola mana yang sampai ke tanah terlebih dahulu (hambatan udara diabaikan). Untuk lebih jelasnya, perubahan konsep Responen K-21 mengenai konsep gerak jatuh bebas dapat dilihat pada Tabel 8 .

TABEL 8 Perbandingan jawaban pretest dan posttest Responden K-21

\begin{tabular}{|c|c|c|}
\hline & Pretest & Posttest \\
\hline $\begin{array}{l}\text { Problem } \\
\text { Solving }\end{array}$ & $\begin{array}{l}\text { menurot saya bola } \\
\text { yang lebih daholu } \\
\text { sampai ke tanah } \\
\text { adalahbola yang } \\
\text { terbuan dari besi } \\
\text { karena massa besi } \\
\text { dua kaci dari } \\
\text { massa alumoaium } \\
\text { dan benta yang } \\
\text { lebin beiatalcan } \\
\text { capat gaya } \\
\text { gravitasinyadaripada } \\
\text { gaya gravitasi } \\
\text { bolayang ringan. }\end{array}$ & $\begin{array}{l}\text { Pada saat bola } \\
\text { bola lesi dan bola } \\
\text { a lominoium } \\
\text { dilepasican pada saat } \\
\text { Yang bersamaan dan } \\
\text { dari latinggian } \\
\text { Yang sama juga } \\
\text { maka bola besi } \\
\text { besi dan hola } \\
\text { aluminium akan } \\
\text { jatuh bersamaan } \\
\text { katenamassa benda } \\
\text { fidak berpengarch } \\
\text { dan tidak menentu- } \\
\text { kan berat suato } \\
\text { benda. }\end{array}$ \\
\hline
\end{tabular}




\begin{tabular}{|c|c|c|}
\hline & Pretest & Posttest \\
\hline Wawancara & 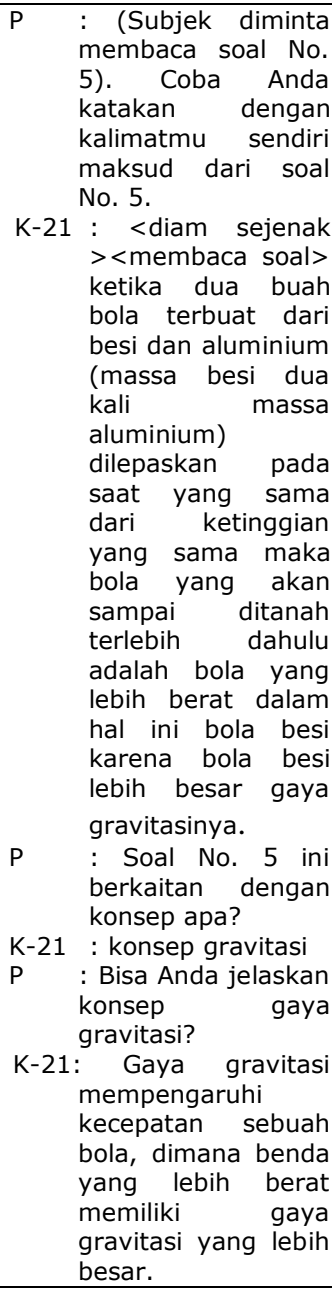 & 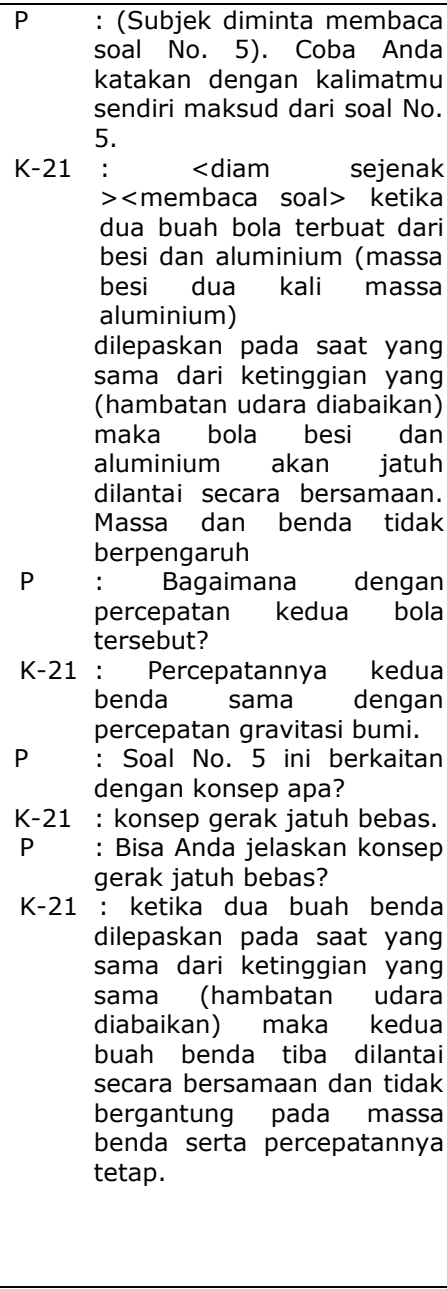 \\
\hline
\end{tabular}

Berdasarkan Tabel 8, dapat dilihat bahwa pemahaman responden terkait soal No. 5 memberikan gambaran bahwa Responden K-21 mula-mula belum memahami tentang konsep gerak jatuh bebas, menurut Responden K-21 ketika dua buah bola terbuat dari besi dan aluminium (massa besi dua kali massa aluminium) dilepaskan pada saat yang sama dari ketinggian yang sama (hambatan udara diabaikan) maka bola yang akan sampai di tanah terlebih dahulu adalah bola besi. Responden K-21 masih terikat dengan pengaruh massa dan berat benda. Responden $\mathrm{K}-21$ meyakini bahwa benda yang lebih berat lebih besar gaya gravitasinya dibandingkan benda yang berat sehingga mempengaruhi kecepatan jatuh bola tersebut. Setelah dilakukan proses belajar mengajar dengan menggunakan strategi konflik kognitif Responden K-21 mulai memahami tentang konsep gerak jatuh bebas. Menurut Responden K-21 Ketika dua bola dijatuhkan dari ketinggian yang sama maka kedua bola tersebut akan tiba di tanah secara bersamaan dimana massa bola tidak berpengaruh dan percepatan kedua bola sama dengan percepatan gravitasi bumi.

\section{Pembahasan}

Berdasarkan analisis data, diperoleh hasil penelitian yang menunjukkan bahwa kelas tersebut mengalami peningkatan perubahan konsep dapat dilihat pada Gambar 2.

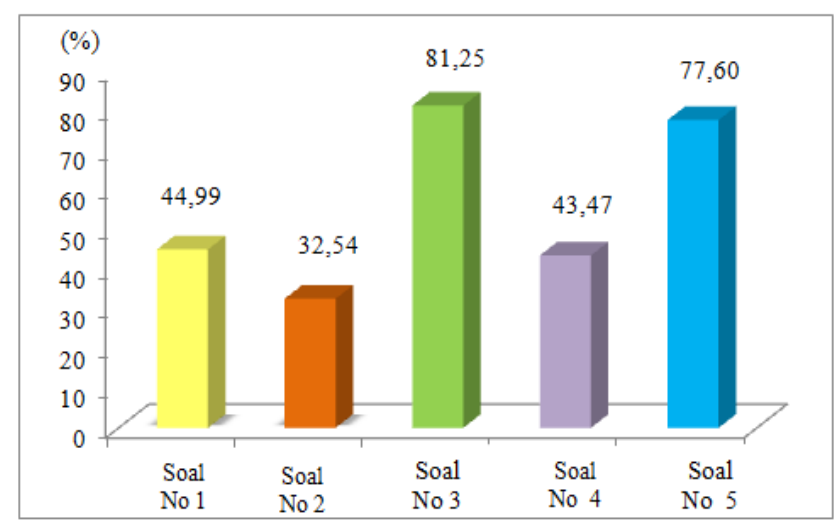

Gambar 2 Perbandingan Rerata N-gain tiap butir soal

Soal No. 1 mengenai konsep gerak relatif. Selama proses pembelajaran berlangsung peneliti yang bertindak sebagai guru memberikan suatu pertanyaan yang dapat menimbulkan konflik kognitif dalam pikiran siswa, bentuk pertanyaannya yaitu dapatkah orang yang duduk dikursi dikatakan bergerak. Kemudian memberikan kesempatan kepada setiap kelompok untuk memaparkan jawabanya, dan semua kelompok menjawab tidak bergerak.

Peneliti melakukan demonstrasi yang dapat menentang pengetahuan awal siswa sehingga dapat bermuara pada perubahan konsep. Contoh demonstrasinya berupa guru meminta bantuan seorang siswa (anggap siswa $A$ ) untuk duduk dikursi dan seorang siswa lagi (anggap siswa B) mendekati siswa A di depan kelas. Demonstrasi diakhiri pertanyaan dari guru "apakah siswa A yang sedang duduk dikursi dikatakan bergerak terhadap siswa B", kemudian siswa serentak menjawab bergerak. Guru kembali mengajukan pertanyaan "apakah siswa B dapat dikatakan bergerak terhadap siswa A", salah satu siswa menjawab bergerak jika titik acuannya siswa A. Guru kembali mengajukan pertanyaan "apakah siswa A yang sedang duduk dikursi dapat dikatakan bergerak terhadap dinding", siswa serentak menjawab tidak bergerak karena siswa A dan dinding sama-sama diam dan tidak terjadi perubahan posisi antara siswa A dengan dinding. Setelah melakukan demonstrasi peneliti berfokus mengamati kepada situasi kelas sesaat setelah memberikan pertanyaan. 
ISSN 23383240

Soal No. 2 mengenai konsep jarak dan perpindahan. Selama proses pembelajaran berlangsung guru memberikan suatu pertanyaan yang dapat menimbulkan konflik kognitif dalam pikiran siswa. Bentuk pertanyaannya "apakah benda yang bergerak selalu memiliki jarak dan besar perpindahan yang sama" dan serentak siswa menjawab ya. Guru kembali mengajukan pertanyaan "suatu benda melakukan perjalanan dari tempat kedudukan A ke C melalui B (jarak dari A ke B adalah $1 \mathrm{~m}$ dan dari $\mathrm{B}$ ke $\mathrm{C}$ adalah $2 \mathrm{~m}$ ) dimana lintasannya berupa garis lurus, berapa jarak dan besar perpindahan yang ditempuh oleh benda tersebut?", salah satu siswa menjawab jarak dan besar perpindahannya $3 \mathrm{~m}$ berarti jarak sama dengan besar perpindahannya. Jarak merupakan panjang lintasan yang ditempuh oleh benda sedangkan perpindahan adalah perubahan posisi suatu benda yang bergantung pada posisi awal dan posisi akhir jadi secara otomatis besar perpindahannya adalah panjang garis yang ditarik dari posisi awal ke posisi akhir. Guru kembali mengajukan pertanyaan "jika benda tersebut bergerak dari A ke $C$ kemudian berbelok arah ke B, berapa besar jarak dan besar perpindahan yang ditempuh oleh benda tersebut" Guru berfokus mengamati situasi kelas setelah memberikan pertanyaan. Guru memberikan pertanyaanpertanyaan yang dapat menentang pengetahuan awal siswa sehingga dapat bermuara pada perubahan konsep.

Soal No. 3 mengenai konsep kelajuan. Selama proses pembelajaran guru memberikan pernyataan yang dapat menimbulkan konflik dalam pikiran siswa, bentuk pernyataannya "Husein berlari $10 \mathrm{~m} / \mathrm{s}$ kearah selatan. Dari pernyataan tersebut dapat dikatakan bahwa kelajuan pelari tersebut $10 \mathrm{~m} / \mathrm{s}$ sedangkan kecepatan $10 \mathrm{~m} / \mathrm{s}$ kearah selatan". Guru mencoba menimbulkan konflik dalam pikiran siswa dengan mengajukan pertanyaan "Dari pernyataan di atas apa yang Anda ketahui tentang kelajuan dan kecepatan?". Siswa menjawab kalau kelajuan hanya bergantung pada nilai (Kelajuan pelari $10 \mathrm{~m} / \mathrm{s}$ ) sedangkan kecepatan memiliki nilai dan arah (kelajuan pelari $10 \mathrm{~m} / \mathrm{s}$ kearah selatan). Guru kembali mengajukan pertanyaaan "apa perbedaan antara kelajuan dan kecepatan" Peneliti berfokus mengamati situasi kelas sesaat setelah memberikan pertanyaan.

Soal No. 4 mengenai konsep GLB. Selama proses pembelajaran berlangsung guru memberikan data hasil percobaan dari GLB dan GLBB. Siswa disuruh untuk mengidentifikasi hasil percobaan itu dan kemudian guru memberikan pertanyaan-pertanyaan yang dapat menimbulkan konflik dalam pikiran siswa.

Soal No. 5 mengenai konsep gerak jatuh bebas. Selama proses pembelajaran berlangsung diberikan suatu pertanyaan yang dapat memotivasi siswa untuk belajar. Guru kemudian memberikan pertanyaan kepada siswa, bentuk pertanyaannya "jika benda ringan dan benda berat dilepaskan pada saat yang bersamaan dari ketinggian yang sama, manakah yang tiba dilantai terlebih dahulu?" serentak siswa menjawab benda ringan. Kemudian guru melakukan demonstrasi, dua buah kelereng yang massanya berbeda dijatuhkan dalam waktu yang bersamaan dari ketinggian yang sama. Demonstrasi diakhiri dengan pertanyaan "manakah yang duluan tiba dilantai", siswa serentak menjawab kedua kelereng yang massanya berbeda akan tiba dilantai secara bersamaan.

Setelah melakukan demontrasi ternyata prediksi awal siswa salah, ketika dua buah benda dijatuhkan dari ketinggian yang sama (hambatan udara diabaikan) ternyata kedua benda tiba dilantai secara bersamaaan. Guru kembali mengajukan pertanyaan "bukankah berat kedua kelereng berbeda". Guru kembali melakukan demonstrasi.

Demonstrasi yang pertama menggunakan kertas terbentang dan kelereng dilepaskan pada saat yang bersamaan dari ketinggian yang sama. Sebelum melakukan demonstrasi guru meminta prediksi siswa dengan mengajukan pertanyaan "kira-kira mana yang duluan tiba di lantai? Kertas terbentang atau kelereng" dan serentak siswa menjawab kelerang. Guru kembali melakukan demonstrasi, kertas yang terbentang tadi diremas-remas berbentuk gumpalan hampir bulat dilepaskan pada saat yang bersamaan dari ketinggian yang sama. Sebelum melakukan demonstrasi guru kembali meminta prediksi siswa dengan mengajukan pertanyaan "kira-kira mana yang duluan tiba di lantai? Kertas berbentuk gumpalan hampir bulat atau kelereng" dan serentak siswa menjawab kelerang.

Setelah melakukan demonstrasi prediksi awal siswa ternyata salah. Kertas berbentuk gumpalan hampir bulat dan kelerang tiba di lantai secara bersamaan. Guru kembali mengajukan pertanyaan "mana yang lebih besar hambatan udaranya, ketika menggunakan kertas terbentang atau kelereng" dan serentak siswa menjawab kertas terbentang. Guru kembali mengajukan pertanyaan "mengapa" dan salah satu siswa menjawab karena luas permukaan kertas terbentang lebih besar dibandingkan kelereng". 
ISSN 23383240

Guru berfokus mengamati situasi kelas setelah memberikan pertanyaan.

Berdasarkan analisis data yang dilakukan, pembelajaran menggunakan strategi konflik kognitif dalam pengajaran sangat membantu dalam suksesnya perubahan konsep siswa. Hal ini disebabkan dalam pembelajaran strategi konflik kognitif, peneliti menyajikan suatu fenomena fisika yang sering dialami siswa dalam kehidupan sehari-hari. Peneliti melibatkan siswa dalam kegiatan diskusi sekaligus melibatkan siswa dalam melakukan demonstrasi. Upaya demikian dimaksudkan agar mereka memahami secara pribadi sekaligus membentuk skema pengetahuan mereka sendiri berdasarkan pengalaman yang mereka alami di kelas sehingga mereka merasa antusias dan tidak bosan selama mengikuti pembelajaran.

Setelah dilakukan uji hipotesis dengan menggunakan uji Wilcoxon diperoleh $W_{\text {hitung }}=0$ dan $\mathrm{W}_{\text {Tabel }}=35$ pada taraf nyata $\alpha=0,05$. Nilai yang diperoleh $\mathrm{W}_{\text {Tabel }}>\mathrm{W}_{\text {hitung, dengan }}$ demikian $\mathrm{H}_{0}$ ditolak dengan taraf nyata $\alpha=$ 0,05 dan $H_{1}$ diterima. Berdasarkan hasil tersebut diketahui bahwa terdapat peningkatan secara signifikan perubahan konsep siswa pada skor posttest dibandingkan dengan skor pretest. Peningkatan ini terjadi setelah dilakukan proses belajar mengajar menggunakan strategi konflik kognitif. Hasil penelitian ini sejalan dengan hasil penelitian Meidahrianti dkk. yang menemukan bahwa pembelajaran dengan menggunakan strategi konflik kognitif [3] dapat menimbulkan perubahan konseptual pada siswa. Hal ini sejalan dengan penelitian Baser ${ }^{[9]}$ dan Kang [10] bahwa strategi pembelajaran konflik kognitif dapat menyebabkan perubahan konsep siswa.

Berdasarkan analisis data, perubahan konsep yang terjadi pada siswa cukup, hal ini dapat dilihat dari rata-rata $\mathrm{N}$ gain yang diperoleh yaitu $54,36 \%$ dengan kriteria sedang. Seperti yang telah dikatakan sebelumnya, walaupun semua siswa mengalami perubahan konsep secara baik masih terdapat miskonsepsi pada setiap konsep yang ada. Hal ini disebabkan siswa memiliki konsep awal dan ini sangat bersifat resisten. Hasil ini didukung dengan pernyataan Suparno [4] bahwa konsep yang bertentangan dengan teori atau konsep awal siswa tidak selalu diterima. Siswa yang tidak menerima, tidak akan menghasilkan perubahan konsep secara kuat, sedangkan bila menerima akan menghasilkan perubahan konsep secara kuat atau akomodasi.
Beragam metode yang digunakan dalam pembelajaran strategi konflik kognitif ini. Namun pada akhirnya, siswa sendirilah yang mengontrol proses-proses kognitif yang memudahkan mereka memahami gagasangagasan baru dan mendapatkan pemahaman yang lebih baik. Kecakapan mereka dalam mengarahkan usaha belajar dan pemahamam mereka sendiri mengenai apa artinya mempelajari sesuatu merupakan unsur-unsur kunci dalam proses merevisi pemikiran mereka tentang materi tertentu di kelas ${ }^{[2]}$.

\section{KESIMPULAN}

Berdasarkan hasil penelitian dan analisis data maka dapat disimpulkan bahwa pembelajaran dengan menggunakan strategi konflik kognitif dapat mempengaruhi perubahan konsep siswa. Pada kelas yang diteliti mengalami perubahan konsep dan berada dalam kategori sedang.

\section{DAFTAR PUSTAKA}

[1] Suparno, P. (1997). Filsafat Konstruktivisme dalam Pendidikan. Yogyakarta: Kanisius.

[2] Ormrod, Jeanne Ellis. (2008). Psikologi Pendidikan Edisi ke Enam. Jakarta: Erlangga.

[3] Meidaharianti, Zulherman, dan Taufiq. (2014). "Pengaruh Strategi Pembelajaran Konflik Kognitif Terhadap Perubahan Konseptual Siswa Pada Materi Listrik Dinamis Di SMA Negeri 1 Tanjung Batu". Jurnal Inovasi dan Pembelajaran Fisika. 1(1), 48-55.

[4] Suparno, P. (2014). Miskonsepsi dan Perubahan Konsep dalam Pendidikan Fisika. Jakarta: Grasindo.

[5] Pujianto, A. Nurjannah. dan I wayan Darmadi. (2013). "Analisis Konsepsi Siswa Pada Konsep Kinematika Gerak Lurus" Jurnal Pendidikan Fisika Tadulako (JPFT) 1(1), 16-21.

[6] Arikunto, S. (2007). Dasar-Dasar Evaluasi Pendidikan (Edisi Revisi). Jakarta: PT. Bumi Aksara.

[7] Sugiyono. (2011) Metode Penelitian Kuantitatif, Kualitatif, dan $R \& D$. Bandung: Alfabeta.

[8] Sudjana. (2002). Metode Statistika. Bandung : Tarsito.

[9] Baser, M. (2006). "Fostering conceptual change by cognitive conflict based instruction on student understanding of heat and temperature concepts". Eurasia Journal of Mathematics, Science and Technology Education. 2(2). 96-114.

[10] Kang H. Scharmann, L.C. Kang, S. \& Noh, T. (2010). "Cognitive Conflict and Situational Interest as Factors Influencing Conceptual Change". International Journal of Enviromental \& Science Education. 5(4). 383-405. 